\title{
La crisis de la pandemia por el SARS-CoV-2 desde el punto de vista de los neumólogos
}

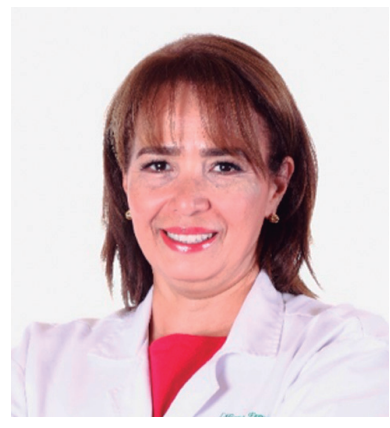

LILIANA FERNÁNDEZ T.

Empezamos el año 2020 con un desconocimiento infinito acerca del nuevo coronavirus del síndrome respiratorio agudo grave tipo 2 (SARS-CoV-2). Hoy podemos ver con mayor claridad los errores, la desinformación inicial y sus consecuencias, el miedo y la manipulación. Es desgarrador el impacto de la pandemia en la economía de nuestro país, pero son inmensos los esfuerzos del Estado y de los profesionales de la salud para sobrellevar esta situación sin precedentes en el último siglo.

Actualmente, en el mundo se han reportado 67 millones de casos y 1,54 millones de fallecimientos. Específicamente para Colombia se ha reportado un total de 1,37 millones de casos con una mortalidad alrededor del 2,76 \%. El compromiso de la comunidad científica a nivel mundial nos ha permitido evolucionar rápidamente; aunque es cierto que aún tenemos poca evidencia de intervenciones farmacológicas que sean efectivas, tenemos mayor claridad de cómo y cuándo se deben ofrecer las diversas herramientas de soporte para el beneficio de los pacientes más comprometidos.

Hemos visto asociaciones y grupos de expertos de todas las especialidades trabajando para llegar a un consenso, tal como se está presentando en esta edición de nuestra revista conformada por una serie de guías de manejo clínico, desde la enfermedad aguda ocasionada por el virus hasta el modo de enfrentarla en los pacientes con alteraciones del sueño que necesitan estudios de diagnóstico, en el laboratorio de función pulmonar, en el manejo de exacerbaciones de asma y enfermedad pulmonar obstructiva crónica (EPOC) y hasta en el cáncer de pulmón. También manifestamos aquí el compromiso absoluto con nuestros pacientes, el deseo de seguir adelante y de aumentar nuestro conocimiento para garantizar un manejo a tiempo, adecuado, con seguridad y de la mejor calidad para todos.

No cabe duda de que debemos seguir trabajando unidos para vencer esta batalla; actualmente nos encontramos frente a una segunda ola del virus. Hemos comprobado cómo países de Europa se han visto forzados a cerrar nuevamente algunos sectores económicos, cómo Estados Unidos se convirtió rápidamente 
en el país con mayor número de casos y esta tendencia persiste a pesar de los esfuerzos. Igualmente, se prevé para Colombia una segunda ola a comienzos del próximo año, que de comportarse como sucedió en el Viejo Continente, tendrá más fuerza que la primera. Existe una inmensa preocupación por el impacto de este nuevo pico en nuestra economía; el efecto de un nuevo cierre sería devastador para la población colombiana.

Ahora más que nunca, desde nuestra posición como profesionales de la salud, debemos actuar con la mayor responsabilidad para dar ejemplo, promover y educar la sociedad. El compromiso es de todos. Debemos aprovechar cada oportunidad de nuestra práctica médica para recordar la importancia del lavado de manos,

Liliana Fernández Trujillo, MD

Editora en jefe

Revista Colombiana de Neumología

Diciembre de 2020 uso de tapabocas y distanciamiento social, así como reducir los miedos irracionales que surgen de la copiosa desinformación a la que se ha visto expuesto el mundo entero. Es uno de los grandes retos que vamos a enfrentar cuando la vacuna, propuesta por diferentes casas farmacéuticas, esté disponible. Es cierto que aún existen muchas dudas de su efectividad y seguridad, pero estas se irán resolviendo en la comunidad científica con métodos y rigurosidad; sin embargo, es probable que persistan en la sociedad y se conviertan en la principal barrera para su aplicación. Depende de la confianza que depositen los colombianos en su sistema de salud para que accedan a la única intervención que podrá ponerle fin a la pandemia y dicha confianza depende de nosotros. 